\title{
Involvement of caspase -8 and -9 in apoptosis in macrophages infected with Actinobacillus actinomycetemcomitans through caspase-3 activation
}

\author{
Emi Harada \\ Division of Periodontology, Department of Cariology and Periodontology, \\ Kyushu Dental College, Kitakyushu, Japan \\ E-mail : inko413@yahoo.co.jp \\ Received October 11, 2006. \\ Accepted November 22, 2006.
}

\begin{abstract}
Actinobacillus actinomycetemcomitans is a facultative intracellular bacterium capable of inducing apoptosis in murine macrophages. In this study, we investigated the caspase cascade in apoptotic cell death of $A$. actinomycetemcomitans-infected macrophages. Flowcytometric analysis revealed that inhibitors of caspase- $3,-8$ and -9 significantly inhibited the apoptotic cell death of infected macrophages. We obtained evidence that infection with $A$. actinomycetemcomitans induced the activation of the caspase -8 and -9 and the executioner caspase- 3 by immunoblot analysis. The activation of caspases induced the cleavage of poly (ADP-ribose) polymerase (PARP). These cleavages were observed within 12 to $18 \mathrm{~h}$ after the infection with $A$. actinomycetemcomitans. The PARP cleavage resulting from activation of the apoptotic pathways was prevented by the caspase- $3,-8$ and -9 inhibitors. These findings indicate that the pathway of $A$. actinomycetemcomitans-induced apoptosis involves the activation of caspases-3, -8 and -9 , and that the activation of caspase- 3 plays an important role in the cleavage of PARP during apoptosis in A. actinomycetemcomitans-infected macrophages.
\end{abstract}

Key words: Actinobacillus actinomycetemcomitans/Caspase/Apoptosis/Poly (ADP-ribose) polymerase

\section{Introduction}

Actinobacillus actinomycetemcomitans, a periodontopathic bacterium, has been implicated in the pathogenesis of several forms of periodontitis, and extracellular components from the bacterium are known to be potent mediators of its adherence to human oral epithelial cells ${ }^{1)}$. In addition, $A$. actinomycetemcomitans has been reported to be a causative agent of various 
infectious diseases, such as endocarditis, pericarditis, meningitis, osteomyelitis, empyema, and subcutaneous abscess ${ }^{2}$.

The initial event in the pathogenesis of most bacterial diseases is microbial adherence to host cells and tissues. After the adhesion to host tissues, some bacteria can invade host cells and cause several disease symptoms in humans. A. actinomycetemcomitans was found to invade oral epithelial cells in vitro ${ }^{3)}$. We developed an in vitro cell culture infection model for A. actinomycetemcomitans and reported the involvement of CD14 molecules in the phagocytosis of $A$. actinomycetemcomitans by macrophages resulting in the subsequent induction of apoptosis ${ }^{4}$.

Apoptosis has been shown to play important roles in the control of various biological systems such as immune responses, hematopoiesis, and embryonic development ${ }^{5)}$. This process is an active cell death, and can be triggered by a variety of pharmacological and physical agents. Recently, it has been shown that Shigella flexneri, the etiologic agent of dysentery, Bordetella pertussis, the causative agent of whooping cough in humans, and periodontopathic bacterium A. actinomycetemcomitans, all induces apoptosis in macrophages ${ }^{6-8}$. Despite the potential importance of apoptosis in infected macrophages as a pathological mechanism, our understanding of its molecular basis and regulation is still minimal.

There is some evidence that apoptosis in infected macrophages is dependent on caspase-1 and $-3^{9,10)}$. It is well known that members of a caspase cascade have been implicated as mediators of apoptotic cell death ${ }^{11}$. Recently, intracellular apoptotic pathways have been classified into two main groups, intrinsic and extrinsic pathways ${ }^{12), 13}$.

We have previously reported that caspase- 1 and -3 are involved in the induction of apoptosis in $A$. actinomycetemcomitans-infected macrophages ${ }^{14)}$. In this study, we used peptide inhibitors for caspases to investigate the possible role of caspase-8, -9 and -3 in the apoptotic cell death of macrophages infected with $A$. actinomycetemcomitans, and clarified a pivotal role of these caspases. We also examined the proteolytic cleavage of PARP, a nuclear enzyme involved in DNA repair, DNA stability, and transcriptional regulation during apoptosis in infected macrophages.

\section{Materials and Methods}

\section{Bacterial strain and growth conditions}

A. actinomycetemcomitans Y4 was grown in brain heart infusion broth (Difco Laboratories, Detroit, MI) supplemented with $1 \%$ (wt/vol) yeast extract at $37{ }^{\circ} \mathrm{C}$ for 2 days in an atmosphere of $5 \% \mathrm{CO}_{2}$ in $\operatorname{air}^{6)}$.

\section{Cell strain and culture conditions}

A murine macrophage cell line J774.1 was obtained from the Japan Cancer Research Resources Bank. Cells were cultured in RPMI medium (GIBCO Laboratories, Grand Island, NY) supplemented with $10 \%$ heat-inactivated fetal calf serum (FCS), penicillin $\mathrm{G}(100 \mathrm{U} / \mathrm{ml})$, and streptomycin $(100 \mu \mathrm{g} / \mathrm{ml})$ at $37^{\circ} \mathrm{C}$ in an atmosphere of $5 \% \mathrm{CO}_{2}$ 
in $\operatorname{air}^{15)}$.

\section{Procedure for A. actinomycetemcomitans infection of macrophages and caspase inhibition assay}

J774.1 cells were plated in a 6 -well plate (IWAKI, Chiba, Japan) at a concentration of $6 \times$ $10^{5}$ cells $/ \mathrm{ml} 1$ day before the experiment. A. actinomycetemcomitans Y4 was harvested by centrifugation and resuspended in RPMI 1640 medium without antibiotics to an optical density of 0.55 at $550 \mathrm{~nm}$, corresponding to approximately $5 \times 10^{9}$ bacterial cells $/ \mathrm{ml}$. The bacterial suspension was added to the cell culture and the plates were centrifuged at $1,000 \times$ $\mathrm{g}$ for $10 \mathrm{~min}$ at $4{ }^{\circ} \mathrm{C}$ prior incubation at $37{ }^{\circ} \mathrm{C}$ for $1 \mathrm{~h}$ in an atmosphere of $5 \% \mathrm{CO}_{2}$ in air. Macrophages infected with $A$. actinomycetemcomitans $\mathrm{Y} 4$ at the final bacterium/cell ratio of 5,000:1 were washed three times with RPMI 1640 medium containing penicillin G, streptomycin, and gentamycin $(200 \mu \mathrm{g} / \mathrm{ml})$ to remove extracellular bacteria. The infected cells were cultured with RPMI 1640 medium containing $5 \% \mathrm{FCS}$ and antibiotics ${ }^{6}$. Inhibitors of caspases-3 (Z-DEVD-FMK), -8 (Z-IETD-FMK), and -9 (Z-LEHD-FMK) were purchased from R\&D SYSTEM, Inc. Minneapolis, MN. Each inhibitor was added to infected J774.1 cells at the final concentration of $50 \mu \mathrm{M}$. The infected J774.1 cells were then cultured in RPMI 1640 medium containing $5 \%$ FCS and antibiotics.

\section{Detection of apoptotic cells}

To measure the percentage of apoptotic cells induced by infection with A. actinomycetemcomitans $\mathrm{Y} 4$, infected $\mathrm{J} 774.1$ cells were suspended in a hypotonic solution ( $0.1 \%$ sodium citrate, $0.2 \% \mathrm{NP}-40,0.25 \mathrm{mg} / \mathrm{ml}$ Rnase, $\mathrm{pH} 8.0$ ), stained in the dark at $4{ }^{\circ} \mathrm{C}$ for 20 min with propidium iodide (PI) $(50 \mu \mathrm{g} / \mathrm{ml})$ and analyzed using an EPICS XL flow cytometer (Beckman Coulter, Fullerton, CA). A cell-cycle phase was performed using MultiCycle for Windows.

\section{Assay for caspase activity}

Following each treatment of J774.1 cells $\left(10^{7}\right.$ cells), caspase activities were measured using colorimetric assay kits (CHEMICON International, Inc. Temecula, CA) according to the manufacturer's instructions. Briefly, caspase activity in cytosolic extracts was measured by spectrophotometric detection of the chromophore $p$-nitroanilide ( $p$-NA) after its cleavage from the labeled substrates ac-DEVD (Asp-Glu-Val-Asp)-pNA. p-NA light emission was quantified using a microtiter plate reader at $405 \mathrm{~nm}$.

\section{Immunoblotting analysis}

J774.1 cells $\left(3 \times 10^{6}\right)$ were infected with $A$. actinomycetemcomitans Y4 with the addition of various caspase inhibitors. After incubating for $18 \mathrm{~h}$, the cells were washed with PBS and lysed by adding $200 \mu 1$ of lysis buffer $(0.05 \mathrm{M}$ Tris- $\mathrm{HCl}$ [pH 6.8], $2 \%$ [wt/vol] SDS, $6 \%$ $\beta$-mercaptoethanol, $10 \%$ glycerol). The lysates were immediately scraped, collected into 
microcentrifuge tubes, and sonicated for $10 \mathrm{~s}$ on ice. The sonicated samples were then centrifuged at $15,000 \times \mathrm{g}$ for $15 \mathrm{~min}$ at $4{ }^{\circ} \mathrm{C}$. Protein concentration was determined using a protein assay kit (Bio-Rad Laboratories Inc., Hercules, CA). Each protein sample $(20 \mu \mathrm{g} /$ line $)$ was loaded on an SDS polyacrylamide gel for electrophoresis at $40 \mathrm{~mA}$. The separated proteins were then electroblotted onto a polyvinylidene difluoride transfer membrane (GE Healthcare Bio-Sciences Corp, Piscataway, NJ). The membranes were washed once with $10 \mathrm{mM}$ Tris- $\mathrm{HCl}$ (pH 7.2) containing $150 \mathrm{mM} \mathrm{NaCl}$ and $0.1 \%$ Tween 20 (TBS-T) and then were blocked for $1 \mathrm{~h}$ in TBS-T containing $5 \%$ (wt/vol) skimmed milk. After washing the membranes with TBS-T, polyclonal antibody against PARP (Cell Signaling TECHNOLOGY, Danvers, MA), either caspase-3 (Cell Signaling TECHNOLOGY) or $\beta$-actin (Santa Cruz Biotechnology, Inc. Santa Cruz, CA) was added at a dilution of 1:1,000 in TBS-T containing $5 \%(\mathrm{wt} / \mathrm{vol})$ skimmed milk and then incubated for $16 \mathrm{~h}$ at $4{ }^{\circ} \mathrm{C}$. After washing three times with TBS-T, the immunoreactive bands were visualized using an ECL plus Western Blotting Detection System (GE Healthcare Bio-Sciences Corp, Piscataway, NJ) according to the manufacturer's instructions.

\section{Immunofluorescence staining}

J774.1 cells were plated in the Lab Tek chamber slide (Nalge Nunc, Rochester, NY) at a concentration of $2 \times 10^{4}$ cells/well 1 day before the experiment. J774.1 cells were infected with A. actinomycetemcomitans Y4 at a bacterium/cell ratio of 5,000:1 as described above. The infected cells were cultured for $18 \mathrm{~h}$ in an atmosphere of $5 \% \mathrm{CO}_{2}$ in air, washed with phosphate-buffered saline (PBS; $\mathrm{pH} 7.2$ ), and then fixed with $4 \%$ paraformaldehyde in PBS for $20 \mathrm{~min}$ at room temperature. The fixed cells were permeabilized with $0.1 \%$ Triton $\times 100$ in PBS for $5 \mathrm{~min}$. Following two washes, the slides were incubated with anti-PARP antibody (Cell Signaling TECHNOLOGY, Danvers, MA) (1:100), followed by Alexa Fluor 488-conjugated goat anti-rabbit IgG antibody (1:1,000) (Invitrogen Corporation, Carlsbad, $\mathrm{CA}$ ) for $1 \mathrm{~h}$ at room temperature. The slides were washed extensively, mounted in a Vectashield mounting medium (Vector Laboratories, Burlingame, CA) and examined with a BX 50 fluorescence microscope (OLYMPUS, Tokyo, Japan) equipped with band-pass optical filter sets appropriate for imaging of the dyes.

\section{Statistical analysis}

All experiments were performed three times with each conducted in triplicate. The means and standard deviations (SD) were then calculated, and the statistical significance of differences among the groups was examined by one-way analysis of variance and a post hoc $t$ test. The post hoc $t$ test was carried out using SPSS $11.0 \mathrm{~J}$ for Windows, and was performed when analysis of variance test results indicated significance, which was determined at $p<0.01$. 


\section{Results}

Inhibitory effects of inhibitors of caspases on apoptosis induced by infection with $A$. actinomycetemcomitans Y4

We examined the percentage of apoptotic J774.1 cells with hypodiploid DNA using flow cytometry. The PI-staining histogram clearly distinguished nuclei with normal diploid DNA from apoptotic nuclei with hypodiploid DNA. J774.1 cells were infected with $A$. actinomycetemcomitans Y4 at a bacterium/cell ratio of 5,000:1. After the infected cells had been incubated for $36 \mathrm{~h}$, the percentage of the cells with hypodiploid DNA was $31.8 \%$. Treatment with the inhibitors of caspases $-3,-8$, and -9 of the infected cells significantly reduced the percentage of the cells with hypodiploid DNA. (Figs. 1 and 2)

\section{Activation of caspase-3 induced by $A$. actinomycetemcomitans Y4 infection}

To further demonstrate the pathway for activation of caspase-3 in the infected macrophage, we examined the kinetics of cleavage of caspase- 3 by immunoblot analysis (Fig. 3). Cleavage of the $32-\mathrm{kDa}$ immature form of caspase- 3 into the $17-\mathrm{kDa}$ active form in $A$. actinomycetemcomitans-infected cells was detected $12 \mathrm{~h}$ after infection. Both inhibitors of caspase-8 and -9 clearly blocked the cleavage of $32-\mathrm{kDa}$ caspase-3 at least $24 \mathrm{~h}$ after infection. In addition, we measured caspase-3 activities in cytosol of $A$. actinomycetemcomitans Y4 infected cells using colorimetric assay. The activity of caspase-3 clearly
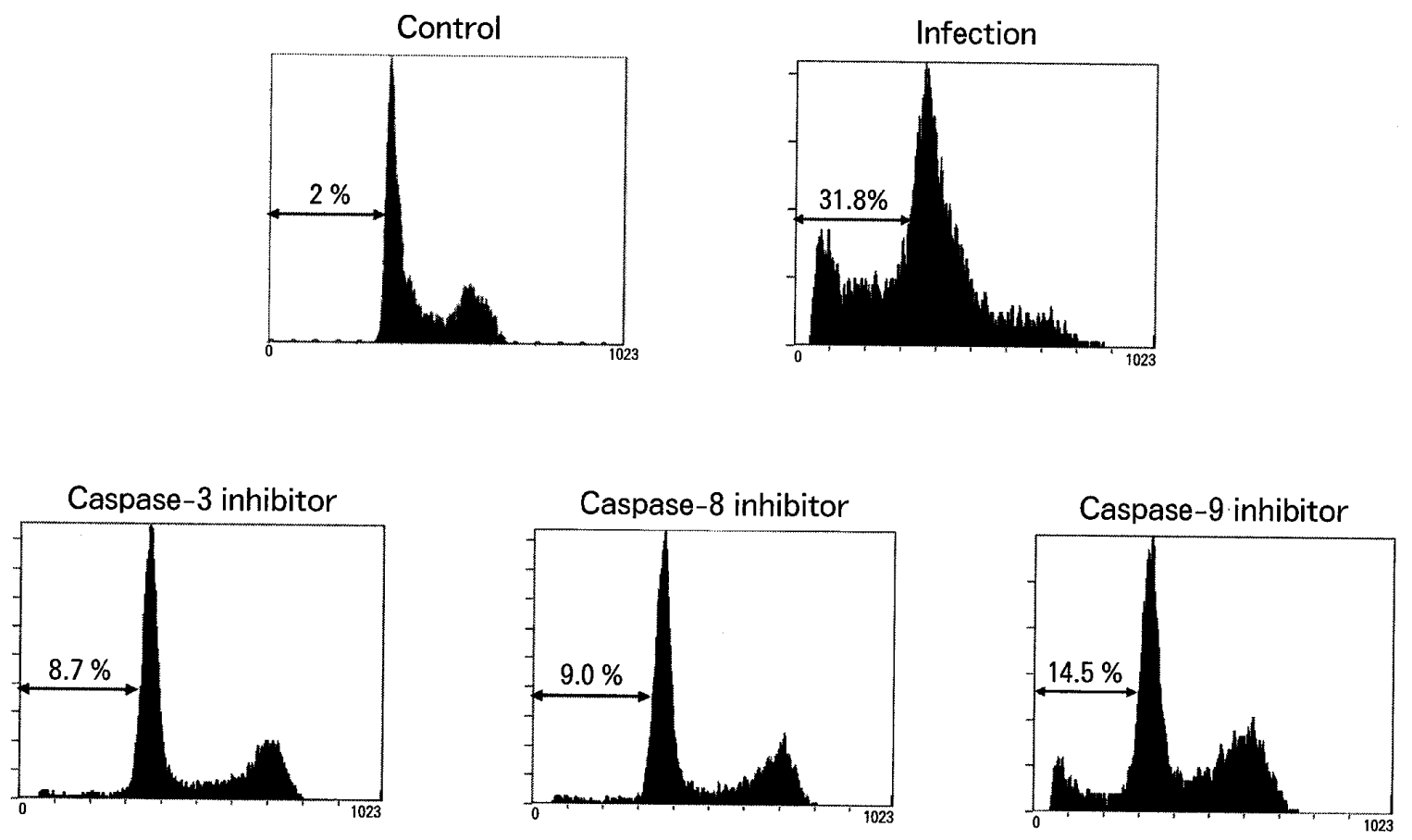

Fig. 1 Analysis of DNA content in J774.1 macrophage cells induced by A. actinomycetemcomitans Y4 infection. J774.1 cells were infected with $A$. actinomycetemcomitans Y4 at a bacterium/cell ratio of $5,000: 1$. Percentages indicated in histograms are ratios of cells containing hypodiploid DNA. 


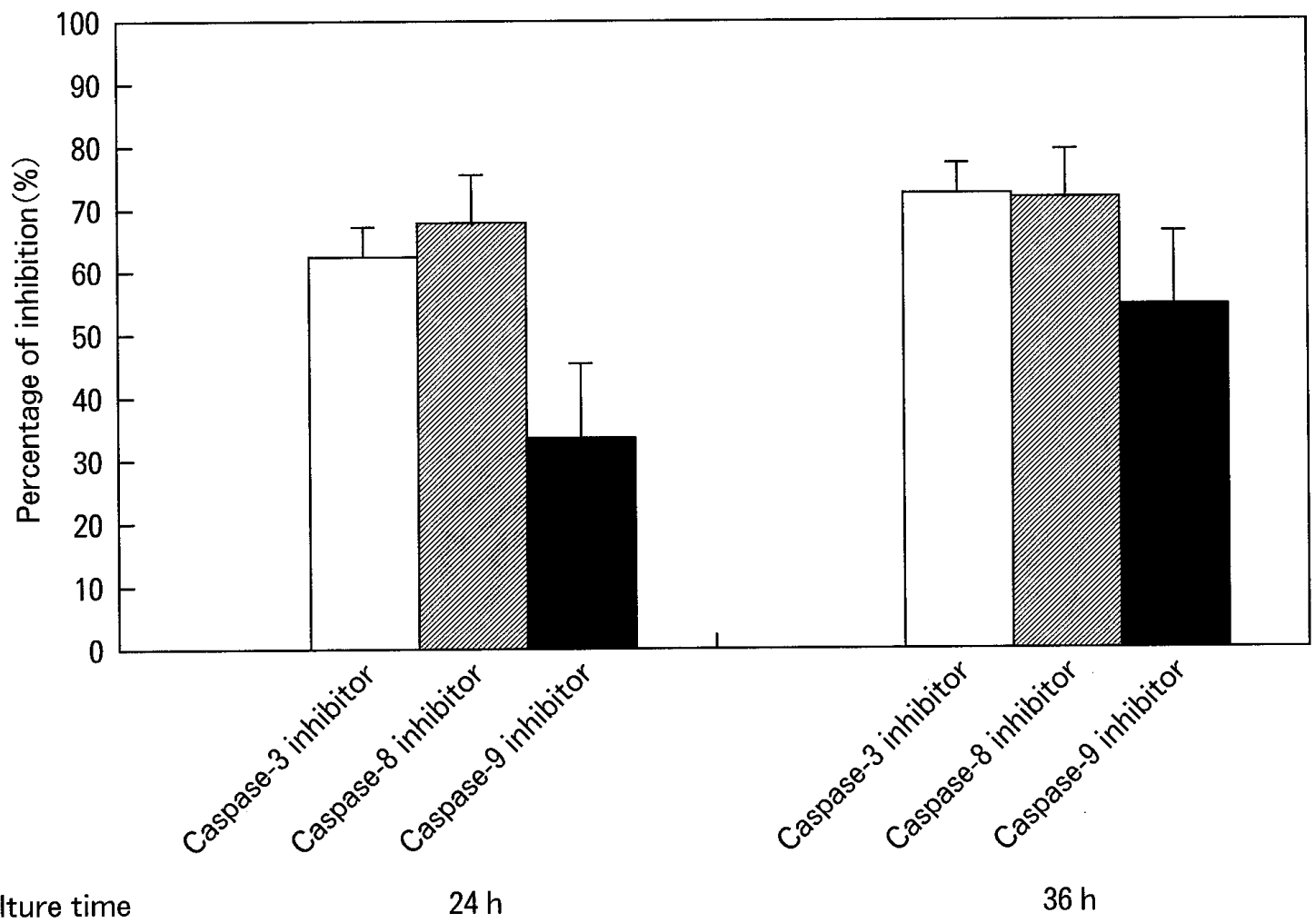

Fig. 2 Effect of various caspase inhibitors on apoptosis induced by A. actinomycetemcomitans Y4 infection. J774.1 cells were infected with $A$. actinomycetemcomitans $\mathrm{Y} 4$ at a bacterium/cell ratio of 5,000:1, and cultured with caspase inhibitors. Percent of inhibition was calculated using the following formula : percent inhibition $=100 \times(1$ - amount of hypodiploid DNA with caspase inhibitor/amount of hypodiploid DNA without caspase inhibitor). Data are expressed as the means \pm S.D. of triplicate samples. The experiment was performed three times and similar results were obtained from each experiment.

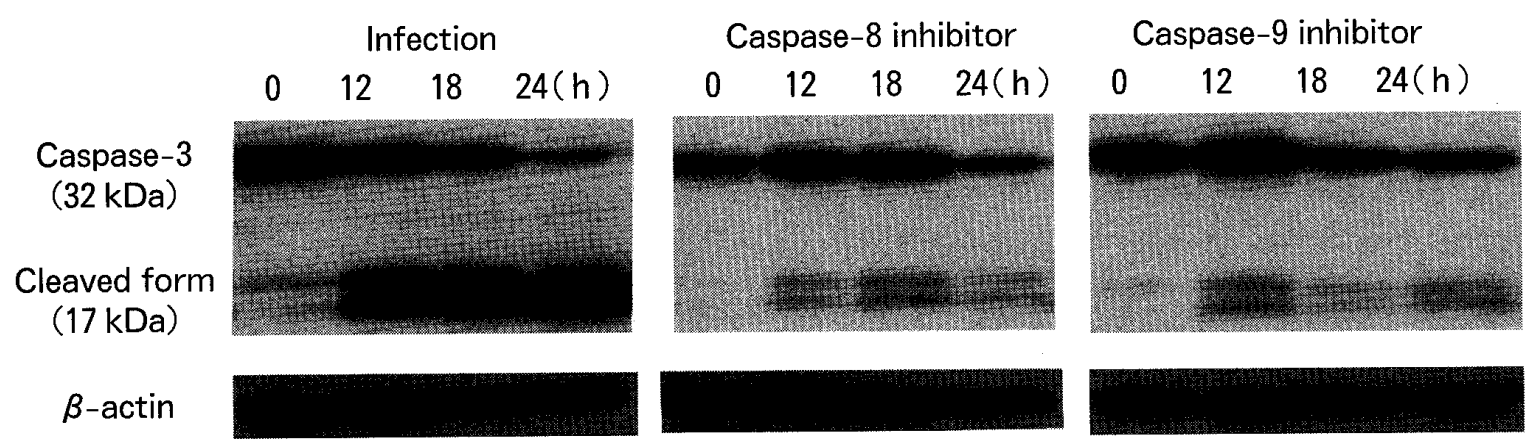

Fig. 3 Cleavage of $32-\mathrm{kDa}$ caspase-3 induced by A. actinomycetemcomitans Y4 infection. After being infected with $A$. actinomycetemcomitans, the cells were cultured with caspase-8 or -9 inhibitor. The cleavage of $32-\mathrm{kDa}$ caspase -3 in the cells was evaluated by an immunoblotting assay as described in materials and methods. The internal control of this experiment was evaluated with the amount of $\beta$-actin. 


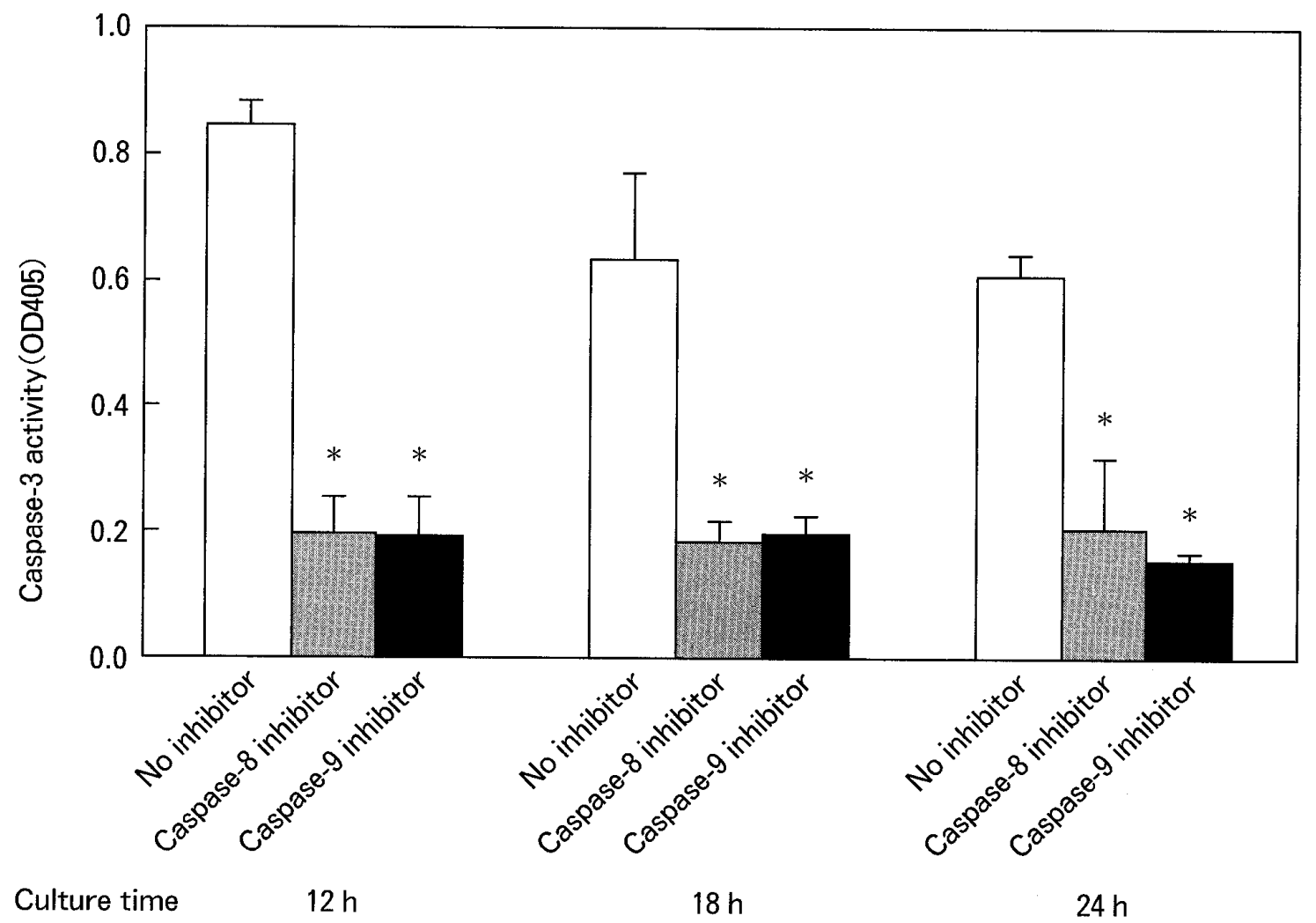

Fig. 4 Activity of caspase-3 induced by A. actinomycetemcomitans Y4 infection. Following infection and each treatment with caspase- 8 or -9 inhibitor, activity of caspase- 3 in the cytosol was evaluated by a colorimetric assay as described in materials and methods. Data are expressed as the means \pm S.D. of triplicate samples. The experiment was performed three times and similar results were obtained from each experiment. Significant differences were determined $(p<0.01)$ and indicated with asterisks.

increased in $A$. actinomycetemcomitans-infected cells. Interestingly, either inhibitors caspase- 8 or -9 significantly reduced the activity of caspase-3 at least $24 \mathrm{~h}$ after infection (Fig. 4).

\section{Degradation of PARP induced by $A$. actinomycetemcomitans Y4 infection}

We previously reported that the activation of caspase- 3 was involved in macrophage apoptotic cell death induced by infection with $A$. actinomycetemcomitans Y4. To confirm the activity of caspase- 3 in vivo, we observed degradation of one of its natural substrates, PARP, by immunofluorescence microscopy. As shown Fig. 5, the fluorescence of Alexa-labeled PARP clearly diminished around nuclei of the A. actinomycetemcomitans-infected cells. To further demonstrate caspase-3 activity, we examined the kinetics of cleavage of PARP by immunoblot analysis of cell lysates (Fig. 6). Cleavage of 116-kDa PARP into the signature 24-kDa small fragment in A. actinomycetemcomitans-infected cells was detected $12 \mathrm{~h}$ after infection. Cleavage of PARP was clearly blocked in cells infected with $A$. actiomycetemcomitans in the presence of the caspase- 3 specific inhibitor for $18 \mathrm{~h}$ after infection. Interestingly, both inhibitors of two independent initial-caspases, caspases-8 and -9 , significantly reduced the peak of the small fragment of $18 \mathrm{~h}$ cultures (Fig. 6). 
A

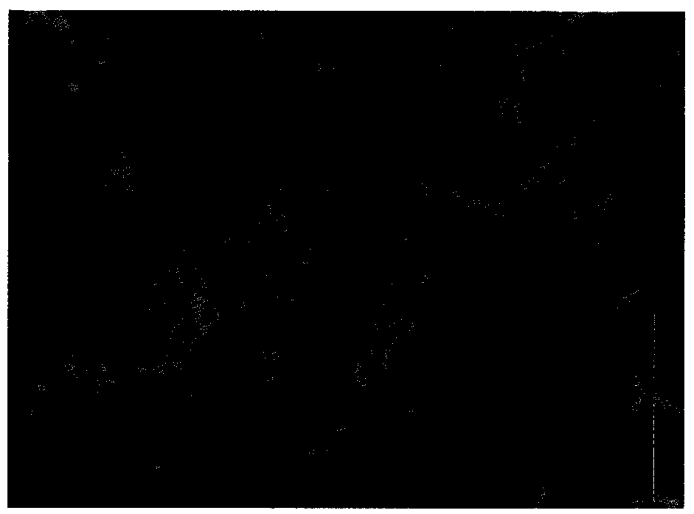

C

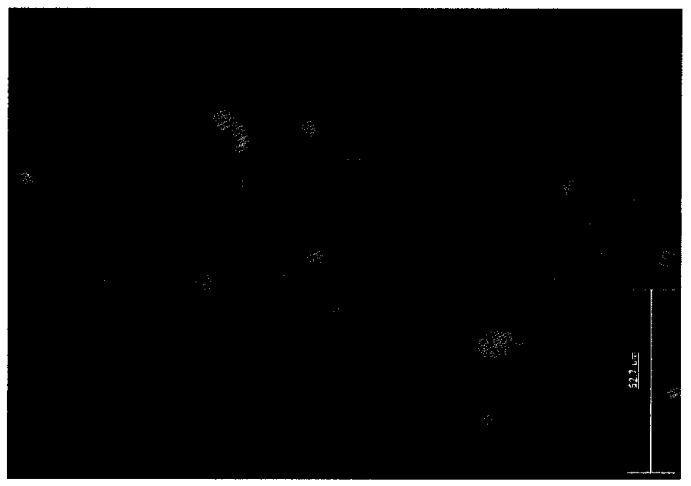

B

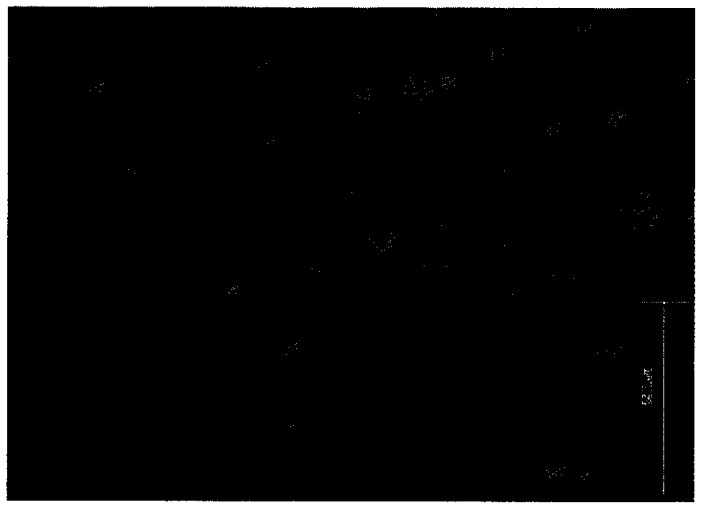

D

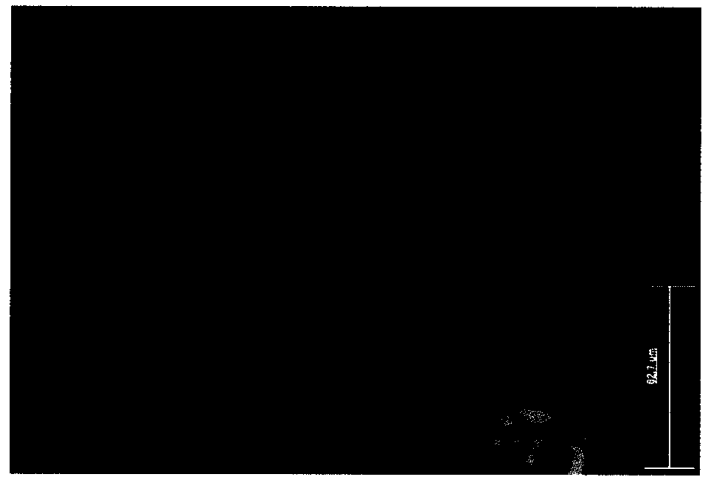

Fig. 5 Observation of Alexa-labeled PARP by fluorescence microscopy. Normal J774.1 cells (A). A. actinomycetemcomitans-infected J774.1 cells at a bacterium/cell ratio of 50:1 (B), 500:1 (C), or 5,000:1 (D). The degradation of PARP in A. actinomycetemcomitans-infected cells was evaluated by immunofluorescence microscopy as described in materials and methods.

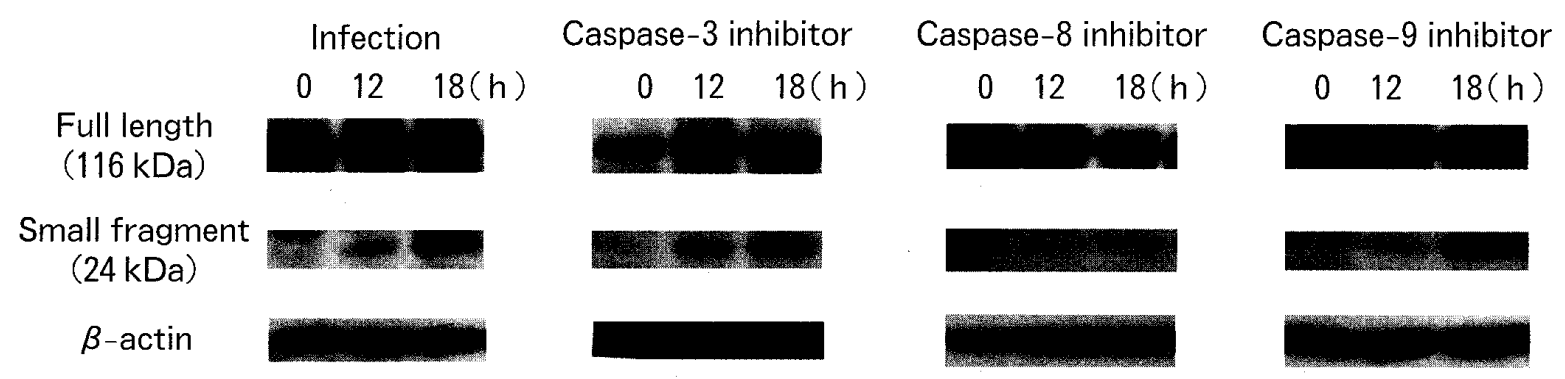

Fig. 6 Cleavage of PARP induced by A. actinomycetemcomitans Y4 infection. After treatment with various caspase inhibitors, cleavage of PARP in $A$. actinomycetemcomitans-infected cells was evaluated by an immunoblotting assay as described in materials and methods. The internal control of this experiment was evaluated with the amount of $\beta$-actin.

\section{Discussion}

The initial interaction in the pathogenesis of most bacterial infectious diseases is microbial invasion of host cells after the microorganisms adhere to some host tissues. Also it is easy for periodontopathic bacteria, such as Porphyromonas gingivalis and A. actinomycetemcomitans, 
to invade macrophages which are known as professional phagocytic cells, by phagocytosis. We have reported that $A$. actinomycetemcomitans can induce apoptosis in mouse macrophages in vitro culture system, however, $P$. gingivalis strains can not ${ }^{6}$. We speculate that the ability of $A$. actinomycetemcomitns to promote apoptosis might be important in the induction of aspiration pneumonia as well as severe periodontitis. Interestingly, we found that mouse alveolar macrophages underwent apoptosis when being infected with A. actinomycetemcomitansin vitro (unpublished data). In addition, it is well known that $A$. actinomyctemcomitans is a causative agent of systemic infectious diseases, such as endocaditis, pericarditis, maningutis and osteomyelitis ${ }^{2}$. Although there are many reports concerning the pathogenesity of $A$. actinomycetemcomitans in the induction of systemic diseases as well as severe periodontitis, our understanding of its molecular basis is still minimal.

The apoptotic signal involves activation of cysteine proteases which are designated caspases. To date, more than ten caspases have been identified and partially characterized concerning the role of induction of apoptosis. The complex cascade of caspase activation is well known to be specific to apoptosis, and caspase- 8 or caspase- 9 activates caspase-3 which in turn cleaves several intracellular proteins, and leads to the initiation of apoptosis ${ }^{16}$. In this study, we examined the possible involvement of caspases, especially caspase- 8 and -9 , in apoptosis in macrophages infected with the periodontopathic bacterium A. actinomycetemcomitans. As shown in Figures 1 and 2, the peptide inhibitors of caspase-8, -9 and -3 blocked apoptosis in $A$. actinomycetemcomitans-infected macrophages. These findings are in accord with the report showing that caspase- 3 is a downstream effector in a caspase cascade and is implicated in many different apoptotic processes ${ }^{16)}$.

It is well known that apoptosis occurs through two types of pathways: the death receptor pathways (extrinsic apoptotic pathways) and the mitichondrial pathways (intrinsic apoptotic pathways). The intrinsic pathway requires the release of cytochrome $\mathrm{c}$ from the mitochondria to the cytosol and the cytochrome $c$ release is a crucial event in the activation

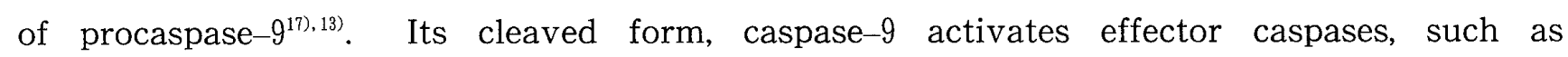
caspases-3, -6 and $-7^{18}$. We have previously reported that apoptosis in $A$. actinomycetemcomitans-infected J774.1 cells is regulated by the release of cytochrome c from mitochondria into cytoplasm, suggesting that intrinsic apoptotic pathways may play an important role in the induction of macrophages infected with periodontopathic bacterium ${ }^{15}$.

The extrinsic pathway forms the death signaling complex that ultimately activates caspase- $8^{19}$. It is thought that caspase- 8 can directly activate caspase- 3 to cleave a variety of intracellular substrates without the contribution of cytochrome $\mathrm{c}$ from the mitochondria. In general, the binding of FasL to Fas results in the recruitment of an adaptor protein, Fas-associated death domain, which associates with a proenzyme form of caspase- 8 and leads to the activation of caspase-8, leading to the activation of downstream caspase- 3 and subsequent degradation of nuclear proteins ${ }^{20)}$. In this study, we found that the peptide inhibitors of not only caspase- 9 but also caspase- 8 inhibited the activation of caspase- 3 (Figs. 3 and 4 ) and the degradation of PARP by immunoblot analysis (Fig. 6). In addition, 
we confirmed that the fluorescence of Alexa-labeled PARP was completely diminished around nuclei in A. actinomycetemcomitans-infected J774.1 cells (Fig. 5). These findings suggest that extrinsic apoptotic pathways may also contribute to apoptosis in macrophages infected with periodontopathic bacteria. We have no ready explanation for this mechanism nor an answer for the question whether Fas-FasL interaction contributes in this process, but we think the degradation by the extracellular components derived from A. actinomycetemcomitans may be a cause. Studies are under way to define clearly the nature of these molecules and to confirm their identity.

Apoptotic cells show multiple changes including membrane blebbing, cytoplasm condensation, and degradation of chromosomal DNA into oligomers of $180 \mathrm{bp}$. It is well known that these morphological and biochemical changes are promoted by caspases during apoptosis, and that the activated caspases cleave multiple cytoplasmic and nuclear substances, and the DNA-repair enzymes PARP ${ }^{11}$. In this study, we found that infection with $A$. actinomycetemcomitans induced apoptosis in macrophages through potent activation of both caspase- 8 and -9 , resulting in activation of effector caspase- 3 and cleavage of its cellular target protein, PARP. These findings suggest that the cleavage of PARP by the sequential activation of caspases may play an important role in the induction of apoptosis in macrophages infected with $A$. actinomycetemcomitans.

\section{Acknowledgments}

The author would like to extend her gratitude to Dr. Yokota (Division of Periodontology, Department of Cariology and Periodontology), and Dr. Nishihara (Division of Infections and Molecular Biology, Department of Health Promotion) for advice and support for this work.

In addition, the author gratefully thank Dr. Kasai (Division of Periodontology, Department of Cariology and Periodontology), and Dr. Okinaga (Division of Infections and Molecular Biology, Department of Health Promotion) for support in this work.

\section{References}

1) Meyer, D. H. and Fives-Taylor, P. M.: Evidence that extracellular components function in adherence of Actinobacillus actinomycetemcomitans to epithelial cells. Infect. Immun. 61: 4933-4936, 1993.

2) Kaplan, A. H., Weber, D. J., Oddone, E. Z. and Perfect, J. R.: Infection due to Actinobacillus actinomycetemcomitans: 15 cases and review. Rev. Infect. Dis. 11: 46-63, 1989.

3 ) Sreenivasan, P. K., Meyer, D. H. and Fives-taylor, P. M.: Requirements for invasion of epithelial cells by Actinobacillus actinomycetemcomitans. Infect. Immun. 61: 1239-1245, 1993.

4) Muro, M., Koseki, T., Akifusa, S., Kato, S., Kowashi, Y., Ohsaki, Y. Yamato, Y., Nishijima, M. and Nishihara T.: Role of CD14 molecules in internalization of Actinobacillus actinomycetemcomitans by macrophages and subsequent induction of apoptosis. Infect. Immun. 65: 1147-1151, 1997.

5) Raff, M. C.: Social controls on cell survival and cell death. Nature 356: 397-400, 1992.

6) Kato, S., Muro, M., Akifusa, S., Hanada, N., Semba, I., Fuji, T., Kowashi, Y. and Nishihara, T.: Evidence for apoptosis of murine macrophages by Actinobacillus actinomycetemcomitans infection. Infect. Immun. 63: 3914-3919, 1995. 
7) Khelef, N., Zychlinsky, A. and Guiso, N.: Bordetella pertussis induces apoptosis in macrophages: role of adenylate cyclase-hemolysin. Infect. Immun. 61: 4064-4071, 1993.

8) Zychlinsky, A. M., Prevost, C. and Sansonetti, P. J.: Shigella flexneri induces apoptosis in infected macrophages. Nature 358: 167-169, 1992.

9) Hilbi, H., Moss, J. E., Hersh, D., Chen, Y., Arondel, J., Banerjee, S. Flavell, R. A., Yuan, J., Sansonetti, P. J. and Zychlinsky, A.: Shigella-induced apoptosis is dependent on caspase--1 which binds to IpaB. J. Biol. Chem. 273: 32895-32900, 1998.

10) Lai, X. and Sjostedt, A.: Delineation of the molecular mechanisms of Francisella tularensis-induced apoptosis in murine macrophages. Infect. Immun. 71: 4642-4646, 2003.

11) Cohen, G. M.: Caspase: the executioners of apoptosis. Biochem. J. 326: 1-16, 1997.

12) Budihardjo, I., Oliver, H., Lutter, M., Luo, X. and Wang, X.: Biochemical pathways of caspase activation during apoptosis. Annu. Rev. Cell. Dev. Biol 15: 269-290, 1999.

13) Krammer, P. H.: CD95's deadly mission in the immune system. Nature 407: 789-795, 2000.

14) Nonaka, K., Ishisaki, A., Okahashi, N., Koseki, T., Kato, S., Muro, M., Nakashima, K., Nishihara, T. and Kowashi, Y.: Involvement of caspase in apoptotic cell death of murine macrophages infected with Actinobacillus actinomycetemcomitans. J. Periodontal. Res. 36: 40-47, 2001.

15) Kasai, H., Yamamoto, K., Koseki, T., Yokota, M. and Nishihara, T.: Involvement of caspase activation through release of cytochrome $\mathrm{c}$ from mitochondria in apoptotic cell death of macrophages infected with Actinobacillus actinomycetemcomitans. FEMS. Microbiol. Lett. 233: 29-35, 2004.

16) Thornberry, N. A. and Lazebnik, Y.: Caspases: enemies within. Science 281 1312-1316, 1998.

17) Kluck, R. M., Bossy-Wetzel, E. and Green, D. R.: The release of cytochrome c from mitochondoria: A primary site for Bcl-2 regulation of apoptosis. Science 275: 1132-1136, 1997.

18) Srinivasula, A. M., Ahmad, M., Alnemri, T. F. and Alnemri, E. S.: Autoactivation of procaspase-9 by Apaf-1 mediated oligomerization. Mol. Cell. 1: 945-957, 1998.

19) Medema, J. P., Scaffidi, C., Kischkel, F. C., Shevchenko, A., Mann, M., Krammer, P. H. and Peter, M. E.: FLICE is activated by association with the CD95 death-inducing signaling complex (DISC). EMBO J. 16: 2794-2804, 1997.

20) Granville, D. J., Carthy, C. M., Hunt, D. W. and McManus, B. M.: Apoptosis: molecular aspects of cell death and disease. Lab. Invest. 78: 893-913, 1998. 


\author{
Actinobacillus actinomycetemcomitans に感染した \\ マクロファージのアポトーシスにおけるカスペースー3を \\ 通じたカスペース $-8,-9$ の関与 \\ 原田依美 \\ 九州歯科大学口腔治療学講座歯周病制御再建学分野
}

抄録

近年, 歯周病原菌によって発症する全身疾患が特に注目され, 国内外の研究者から数多くの研究成果が報告さ机て いる。なかでも若年性蒾周焱や難治性歯周炎の原因菌として考えられているActinobacillus actinomycetemcomitans は，これらの疾患のみならず，全身疾患を引き起こすことが知られている。

感染症の成立には, 病原微生物が組織に定着し增殖することが必須であるが, これまでの研究で A. actinomycetemcomitans はマクロファージ内に侵入し，アポトーシスを誘導することが明らかとなり，感染症の発症との関わり できわめて興味樑い研究テーマとなってきた。 そこで本研究では，A. actinomycetemcomitansに感染したマクロ ファージのアポトーシス誘導の過程における caspase-8 および caspase-9 の関与について検討した.

マウスマクロファージであるJ774.1にA. actinomycetemcomitans Y4 株を細菌/細胞比 $5000: 1$ で感染させた。ま ず，J774.1を caspase-3，-8，-9 阻害剂存在下で A. actinomycetemcomitans よ培養し，アポトーシス細胞の出現を フローサイトメーターで検討した．これまでの知見で, caspase-3 は caspase-8 および caspase-9 によって活性化す ることが知られているので, 感染させた J774.1 細胞に caspase-9 阻害浏を添加し， caspase-3 の活性化について検討 した，興味深いことに，A. actinomycetemcomitans 感染マクロファージでは， caspase-8 および caspase-9を介し た経路で別々に caspase-3 が活性化されることが明らかとなった.ささら A. actinomycetemcomitans 感染マク口 ファージ内で caspase-8 および caspase-9 で活性化された caspase--3により細胞内タンパクである poly（ADPribose) polymerase（PARP）が分解されることが明らかとなった。この結果から，A. actinomycetemcomitans 感 染マクロファージのアポトーシス誘導時特有の形態変化には, caspase-8, caspase-9 および caspase-3 の活性化が 関与していることが強く示唆された。

今回の研究で, 歯周病細菌 A. actinomycetemcomitans が主要な感染防御細胞であるマクロファージをアポトーシ スに導くメカニズムの一端が明らかとなった．今後，上り詳細な誘導メカニズムを解明していくっもりである.

キーワード: Actinobacillus actinomycetemcomitans/Caspase/Apoptosis/Poly (ADP-ribose) polymerase 